\title{
Curing of mice skin infections using ethanol flower extract of chamomile
}

\author{
Enass H. Ali*
}

\author{
Munira Ch. Ismail***
}

\begin{abstract}
:
This experiment was conducted in order to estimate azulene and apigenin in chamomile flowers. Ethanol extracts were examined singly or in combination with some drugs in their biological activity against some pathogens causing skin infection. Ethanol extract was applied at a concentration of $40 \mathrm{mg} / \mathrm{ml}$ for the treatment of induced skin infection of mice. Among the topicals used, Claforan was found the most effective on microorganisms causing skin diseases; ethanol extract was more effective than the drug Candimazole solution 1\%. HPLC was used for the determination of azulene and apigenin active compounds of chamomile plant.
\end{abstract}

Key words: chamomile flowers; antimicrobial activity, skin infections

\section{Introduction:}

German

Chamomile

(Matricaria recutita) is a daisy-like flower that blooms from late spring through late summer; it is an annual plant of the composite family Asteraceae [1]. An infusion of the flowers is taken internally as an antiinflammatory, antiseptic,

antispasmodic, carminative, diaphoretic, febrifuge, sedative, stomachic, tonic and vasodilator [2, 3, 4]. The flowers are also used externally to treat wounds, sunburn, burns, haemorrhoids, mastitis and leg ulcers. An infusion is particularly useful as a stomachic, nervine and sedative for young children, especially when they are teething [4].

Skin infections are common and may be caused by bacteria, fungi or viruses. Breaks in the skin integrity, particularly those that inoculate pathogens into the dermis, frequently cause or exacerbate skin infections [5]. The in vivo study of possible therapeutic effect of chamomile extract on bacterial infections was performed on mice skin. The chamomile extracts were prepared and applied locally on the skin of experimentally infected mice described by [6].

Drugs used for skin infections are Claforan (cefotaxime sodium) which has an in vitro activity against a wide range of Gram-positive and Gram-negative microorganisms [7], Acetic acid 6\%, also known as ethanoic acid, is an organic chemical compound, giving sour taste and pungent smell [8]. Fusidic acid is another drug only effective on Grampositive bacteria such as Staphylococcus spp. and Corynebacterium spp., it inhibits bacterial replication and does not kill the bacteria and is therefore termed "bacteriostatic" [9]. Clotrimazole (Candimazole) solution 1\% was also used for treatment of susceptible fungal infections including oropharyngeal candidiasis, dermatophytoses, superficial mycoses and cutaneous candidiasis [10].

*Department of Biotechnology, College of Science, Al-Nahrain University

** Center for Biological Research, Baghdad University 
HPLC is used for the determination of flavonoids and has become a popular method for separation, screening and quantitative analysis of plant, food products and also herbal medicines [11, 12, 13]. This paper addresses the potential of using chamomile flower ethanol extract in treatment of skin inflammations compared with some commonly used drugs.

\section{Materials and Methods:}

Chamomile dried flowers were bought from a local market and identified as a German chamomile by specialist. The microorganisms Candida albicans, Pseudomonas aeruginosa and Staphylococcus aureus were obtained from Biotechnology Dept., College of Science, Al-Nahrain University.

A quantity of $50 \mathrm{~g}$ of flowers powder was extracted with $250 \mathrm{ml}$ of $75 \%$ ethanol by soxhlet apparatus for 6 hrs. at $40-60^{\circ} \mathrm{C}$. The suspension was filtered through a filter paper (Whatman no.1), and then the solvent was removed under reduced pressure by using rotary evaporator at $40^{\circ} \mathrm{C}$, filter-sterilized using Millipore unit $(0.22 \mu \mathrm{m})$. The crude solid extract (24g) was kept in a deep freeze until use [14].

The activity of the extracts was determined against target microorganisms (S. aureus, $P$. aeruginosa and $C$. albicans) in vitro by using modified agar diffusion method describe by [15].

The extract was prepared at three concentrations 10,20 or 40 $\mathrm{mg} / \mathrm{ml}$. The dried alcohol extract was redissolved with alcohol (75\% ethanol).

The Tryptone soya agar medium was mixed well and aliquots of $20 \mathrm{ml}$ were poured in Petri-dishes. The medium was inoculated with 0.1 $\mathrm{ml}$ of $\left(1.5 \times 10^{8} \mathrm{CFU} / \mathrm{ml}\right)$ target isolates of $S$. aureus, $P$. aeruginosa or $C$. albicans by using sterile swabs.

Four evenly spaced wells, $3 \mathrm{~mm}$ in diameter were made in the agar of each plate with sterile cork borer. To identify the intrinsic extracts activity, one control well was filled with (100 $\mu \mathrm{l})$ phosphate buffer saline (PBS). Equal volumes of the three concentrations 10,20 or $40 \mathrm{mg} / \mathrm{ml}$ of the extracts were dispensed into each well (three replica plates were prepared for each agent). Test plates were then incubated at $37^{\circ} \mathrm{C}$ for $24 \mathrm{hrs}$. and zones of inhibition were measured using a ruler. A clear zone indicated that the extract showed its antibacterial or antifungal activity. This method was repeated three times for each test. (The values were averaged for the three experiments).

The activity of the drugs (Cefotaxime sodium, Fusidic acid, Clotrimazole and Acetic acid 6\%) that were used for treatment of human skin infection was investigated. The effect of chamomile flower ethanol extract individually or combined with these drugs were determined by using modified agar diffusion method.

In this study, two groups (A and B) of mice were experimented; each group included twelve mice which were divided into four subgroups represented by three mice for each. The experiment was conducted as follows: The hair on the back of mice was shaved, and the area was cleaned and disinfected with cotton swab saturated with $70 \%$ alcohol, direct scraping of the skin was done by sterile pathological scalpel to make abrasion on one half of the mouse's back skin and the skin of each group was subjected to the infections as stated below (mice were treated with different treatments daily):

Group A: represented by twelve mice, this was divided into four subgroups representing three mice for each. The 
scratched skin infected with $0.1 \mathrm{ml}$ of S. aureus suspension $\left(1.5 \times 10^{8} \mathrm{CFU} / \mathrm{ml}\right.$ by McFarland) from an overnight $S$. aureus grown culture. The signs of a wound infection exhibited redness, swelling, and pus appeared after 10 days.

The first subgroup: each of the three mice was smeared by a suspension of $S$. aureus and after ten days of the infection, the infected skin was treated with $0.1 \mathrm{ml}$ (the drug Cefotaxime sodium $125 \mathrm{mg} / \mathrm{ml}+$ chamomile flower ethanol extract $20 \mathrm{mg} / \mathrm{ml}$ ) at $50 \%$ from each. This group was used for infection and treatment of mice.

The second subgroup: each of the three mice was smeared by a suspension of $S$. aureus and after ten days of the infection, the infected skin was treated with $0.1 \mathrm{ml}$ of the drug Cefotaxime sodium $(250 \mathrm{mg} / \mathrm{ml})$.

The third subgroup: each of the three mice was smeared by a suspension of $S$. aureus and after ten days of the infection, the infected skin was treated with $0.1 \mathrm{ml}$ of the chamomile flower ethanol extract $(40 \mathrm{mg} / \mathrm{ml})$.

The fourth subgroup: each of the three mice was smeared by a suspension of $S$. aureus and after ten days of the infection, the infected skin was treated with $0.1 \mathrm{ml}$ of PBS.

Group B: represented by twelve mice, this was divided into four subgroups representing three mice for each. The scratched skin infected with $0.1 \mathrm{ml}$ of C. albicans suspension $\left(1.5 \times 10^{8}\right.$ CFU/ml) from $C$. albicans culture. The signs of a wound infection appeared as redness, swelling, and pus after 10 days.

The first subgroup: each of the three mice was smeared by a suspension of C. albicans and after ten days of the infection, the infected skin was treated with $0.1 \mathrm{ml}$ (Clotrimazole $0.75 \mathrm{mg} / \mathrm{ml}$ + chamomile flower ethanol extract $10 \mathrm{mg} / \mathrm{ml}$ ) at $75 \%$ from each. This group was used for infection then treatment of mice.

The Second subgroup: each of the three mice was smeared by a suspension of $C$. albicans and after ten days of the infection, the infected skin was treated with $0.1 \mathrm{ml}$ of $1 \%$ Clotrimazole.

The third subgroup: each of the three mice was smeared by a suspension of $C$. albicans and after ten days of the infection, the infected skin was treated with $0.1 \mathrm{ml}$ of the chamomile flower ethanol extract $(40 \mathrm{mg} / \mathrm{ml})$.

The fourth subgroup: each of the three mice was smeared by a suspension of $C$. albicans and after ten days of the infection, the infected skin was treated with $0.1 \mathrm{ml}$ of PBS.

\section{HPLC analysis}

Azulene in ethanol extracts was estimated by gradient HPLC. Chromatography conditions: column Tessek SGX C18 $7 \mu \mathrm{m}(4 ¥ 250 \mathrm{~mm})$; flow rate $0.7 \mathrm{ml} \cdot \mathrm{min} 1$; mobile phase $\mathrm{A}$ : acetonitrile/water/ $\mathrm{H}_{3} \mathrm{PO}_{4}$ (19:80:1), B: 45\% acetonitrile, C: $90 \%$ acetonitrile. The linear gradient elution programme from $100 \%$ A to $100 \%$ B for $25 \mathrm{~min}$, then to $100 \% \mathrm{C}$ for $30 \mathrm{~min}$, isocratic for $5 \mathrm{~min}$, and returning to $100 \% \mathrm{~A}$ for $45 \mathrm{~min}$. Detection was performed at $320 \mathrm{~nm}$ of wavelength as described by [16].

Apigenin standard was dissolved in methanol. A stock solution of 0.567 $\mathrm{mg} / \mathrm{ml}$ was prepared. For HPLC calibration curve, concentrations ranged from 0.0567 to $0.567 \mathrm{mg} / \mathrm{ml}$ were prepared.

The analytical method was used with some modifications. Samples were separated on a reversed phase column, Symmetry C18 column (3.9' 150 mm; $5 \mathrm{~mm}$ particle size), manufactured by Waters, USA. The mobile phase consisted of methanol and water in a volume ratio of 50:50 with a flow rate of $0.8 \mathrm{ml} / \mathrm{min}$; all samples were passed through a $0.45 \mu \mathrm{m}$ Millipore filter as described by [17]. 


\section{Results:}

Chamomile flowers ethanol extract exhibited antibacterial activity against microorganisms at the concentration $10 \mathrm{mg} / \mathrm{ml}$ (table 1) and (Fig. 1). The diameter of the inhibition zones against $S$. aureus was $12.1 \mathrm{~mm}$ at concentration of $10 \mathrm{mg} / \mathrm{ml}$. The higher concentrations of extracts 20 and $40 \mathrm{mg} / \mathrm{ml}, S$. aureus showed 13.2 $\mathrm{mm}$ and $15.0 \mathrm{~mm}$, respectively. Results also showed that $P$. aeruginosa gave $29.7 \mathrm{~mm}$ inhibition zones at 10 $\mathrm{mg} / \mathrm{ml}$. While the concentrations of extracts showed $33.2 \mathrm{~mm}$ at $20 \mathrm{mg} / \mathrm{ml}$ and $37.4 \mathrm{~mm}$ at $40 \mathrm{mg} / \mathrm{ml}$ of the chamomile flowers ethanol extract.

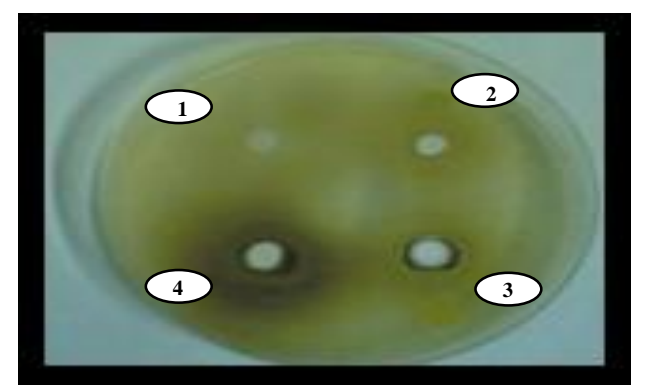

Fig. 1: Inhibition zones $(\mathrm{mm})$ caused by different concentrations of chamomile flower ethanol extract -a- $S$. aureus, -b- P. aeruginosa. $1=$ control (PBS), 2= 10, 3=20, 4= 40.

Table (2) showed the in vitro effect of chamomile ethanol extract on the antibacterial activity of some drugs and treatments that used for curing skin of wounds. Cefotaxime sodium:ethanol extract $50 \%$ recorded the highest diameter of inhibition zone $(70.0 \mathrm{~mm})$ against $S$. aureus, but Cefotaxime sodium:ethanol extract $75 \% \quad(187.5: 10) \mathrm{mg} / \mathrm{ml}$ recorded an inhibition zone reached $61.0 \mathrm{~mm}$ against $P$. aeruginosa while Cefotaxime sodium:ethanol extract at $25 \% \quad(62.5: 30) \mathrm{mg} / \mathrm{ml}$ achieved the highest diameter of inhibition zone (32.1) mm against $C$. albicans.

Acetic acid at $100 \%$ achieved the highest diameter of inhibition zone $(22.0 \mathrm{~mm})$ against $S$. aureus, but Acetic acid at $25 \%(1.5: 30) \mathrm{mg} / \mathrm{ml}$ gave
In Candida, the low concentration $10 \mathrm{mg} / \mathrm{ml}$ showed 21.1 $\mathrm{mm}$ inhibition zones subsequently, 28.1 and $30.4 \mathrm{~mm}$ were recorded at the concentrations of 20 and $40 \mathrm{mg} / \mathrm{ml}$.

Table 1: Diameter of inhibition zones caused by chamomile flower ethanol extract at various concentrations on $S$. aureus, $P$. aeruginosa and $C$.albicans

\begin{tabular}{|c|c|c|c|}
\hline $\begin{array}{c}\text { Concentration } \\
\mathbf{m g ~ d w t} / \mathbf{m l}\end{array}$ & \multicolumn{3}{|c|}{ Diameter of inhibition zone (mm) \pm S.D. } \\
\cline { 2 - 4 } & S. aureus & P. aeruginosa & C. albicans \\
\hline Control (PBS) & $-\mathrm{ve}$ & $-\mathrm{ve}$ & $-\mathrm{ve}$ \\
\hline 10 & $12.1 \pm 0.14$ & $29.7 \pm 0.25$ & $21.1 \pm 0.07$ \\
\hline 20 & $13.2 \pm 0.12$ & $33.2 \pm 0.68$ & $28.1 \pm 0.46$ \\
\hline 40 & $15.0 \pm 0.10$ & $37.4 \pm 0.10$ & $30.4 \pm 0.07$ \\
\hline
\end{tabular}

-ve: no activity was observed

Values are mean of 3 replicates \pm S.D.

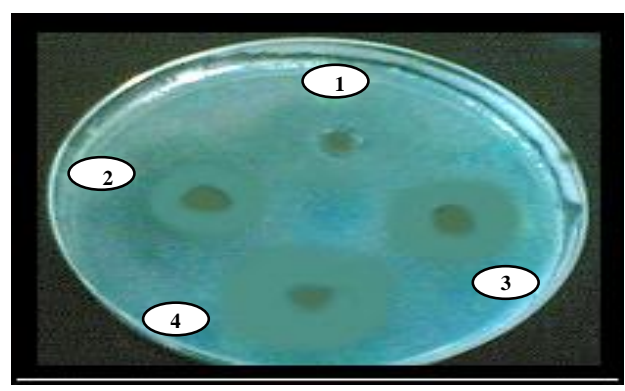

$-b-$

an inhibition zone $13.2 \mathrm{~mm}$ against $P$. aeruginosa but the ethanol extract was better than Acetic acid in a diameter of inhibition zone $(29.7 \mathrm{~mm})$. The Acetic acid $75 \%(4.5: 10) \mathrm{mg} / \mathrm{ml}$ achieved the diameter of inhibition zone $(29.0 \mathrm{~mm})$ while ethanol extract alone produced the largest inhibition zone $(33.5 \mathrm{~mm})$ against $C$. albicans.

Fusidic acid at $100 \%$ achieved the highest diameter of inhibition zone (40.5) against $S$. aureus, but no inhibition zone against $P$. aeruginosa, while giving an inhibition zone 30.5 $\mathrm{mm}$ against $\mathrm{C}$. albicans.

Clotrimazole was tested against C. albicans only. At percentage $75 \%$ $(0.75: 10) \mathrm{mg} / \mathrm{ml}$ achieved a diameter of inhibition zone reached $24.3 \mathrm{~mm}$ compared with the ethanol extract 
which recorded $33.5 \mathrm{~mm}$ inhibition zone and with the Clotrimazole at $100 \%$ which recorded $28.4 \mathrm{~mm}$. The ethanol extract of chamomile at a concentration of $40 \mathrm{mg} / \mathrm{ml}$ and drugs (Cefotaxime sodium and Clotrimazole) showed an obvious destroying effect on $S$. aureus and $C$. albicans in experimentally induced skin infection in mice compared to controls (infection). The infection showed swallowing, redness and filled with pus cells as shown in table (3), (4) and Fig. (2) which represents 2 groups of mice, group A was infected with $S$. aureus, and group B was infected with C. albicans.

The results showed that the better treatment is (Cefotaxime sodium and chamomile ethanol extracts) at $50 \%$, as in table (2) and the results showed that the better treatment is (Chamomile flower ethanol extract) more than Clotrimazole at as in table (3).

Table 2: Antimicrobial activity expressed as a diameter of inhibition zone caused by chamomile flower ethanol extract in combination with some antimicrobial drugs in vitro.

\begin{tabular}{|c|c|c|c|c|}
\hline \multirow[b]{2}{*}{$\begin{array}{c}\text { Drugs } \\
(\%)\end{array}$} & \multirow{2}{*}{$\begin{array}{c}\text { Final } \\
\begin{array}{c}\text { concentrations } \\
(\mathrm{mg} / \mathrm{ml})\end{array} \\
\end{array}$} & \multicolumn{3}{|c|}{ Diameter of inhibition zone $(\mathrm{mm}) \pm$ S.D. } \\
\hline & & S. aureus & $\begin{array}{c}P . \\
\text { aeruginosa }\end{array}$ & $\begin{array}{c}C . \\
\text { albicans }\end{array}$ \\
\hline \multicolumn{5}{|c|}{ Cefotaxime sodium:extract } \\
\hline $25: 75$ & $62.5: 30$ & $60.1 \pm 1.05$ & $48.0 \pm 1.05$ & $32.1 \pm 1.00$ \\
\hline $50: 50$ & $125: 20$ & $70.0 \pm 1.00$ & $50.2 \pm 2.00$ & $31.0 \pm 1.00$ \\
\hline $75: 25$ & 187.5:10 & $65.1 \pm 0.95$ & $61.0 \pm 1.00$ & $28.3 \pm 0.20$ \\
\hline 100:0 & Extract only $250: 0$ & $46.0 \pm 1.00$ & $48.1 \pm 1.00$ & $36.2 \pm 0.95$ \\
\hline $0: 100$ & alcohol extract 40 & $30.1 \pm 1.00$ & $29.7 \pm 1.00$ & $33.5 \pm 2.00$ \\
\hline \multicolumn{5}{|c|}{ Acetic acid 6\%:extract } \\
\hline $25: 75$ & $1.5: 30$ & $18.1 \pm 1.00$ & $13.2 \pm 0.86$ & $22.5 \pm 1.00$ \\
\hline $50: 50$ & $3: 20$ & $19.0 \pm 1.00$ & $15.5 \pm 1.00$ & $27.1 \pm 1.00$ \\
\hline $75: 25$ & $4.5: 10$ & $20.1 \pm 1.10$ & $19.0 \pm 1.00$ & $29.0 \pm 2.00$ \\
\hline 100:0 & Extract only $6 \%: 0$ & $22.0 \pm 1.00$ & $24.0 \pm 1.00$ & $20.0 \pm 1.00$ \\
\hline $0: 100$ & alcohol extract 40 & $30.1 \pm 1.00$ & $29.7 \pm 1.00$ & $33.5 \pm 2.00$ \\
\hline \multicolumn{5}{|c|}{ Fusidic acid:extract } \\
\hline $25: 75$ & $5000: 30$ & $36.0 \pm 1.00$ & - & $32.1 \pm 1.00$ \\
\hline $50: 50$ & $10000: 20$ & $39.1 \pm 1.00$ & - & $40.2 \pm 1.10$ \\
\hline $75: 25$ & $15000: 10$ & $37.2 \pm 1.00$ & - & $37.2 \pm 1.00$ \\
\hline 100:0 & $\begin{array}{c}\text { Extract only } \\
20000: 0\end{array}$ & $40.5 \pm 1.00$ & - & $30.5 \pm 1.00$ \\
\hline $0: 100$ & alcohol extract 40 & $30.1 \pm 1.00$ & $29.7 \pm 1.00$ & $33.5 \pm 2.00$ \\
\hline \multicolumn{5}{|c|}{ Clotrimazole:extract } \\
\hline $25: 75$ & $0.25: 30$ & * & * & $24.0 \pm 1.00$ \\
\hline $50: 50$ & $0.50: 20$ & $*$ & * & $21.1 \pm 1.00$ \\
\hline $75: 25$ & $0.75: 10$ & $*$ & * & $24.3 \pm 1.00$ \\
\hline 100:0 & Extract only $1 \%: 0$ & $*$ & $*$ & $28.4 \pm 1.00$ \\
\hline $0: 100$ & alcohol extract 40 & * & $*$ & $33.5 \pm 2.00$ \\
\hline
\end{tabular}

Values are mean of 3 replicates \pm S.D.

* Not tested since Clotrimazole is a fungicide- No inhibition zone
Table 3: Effect of different treatments on curing of mice skin infected with $S$. aureus in four experimental mice subgroups

\begin{tabular}{|c|c|c|}
\hline $\begin{array}{c}\text { Sub grouping of } \\
\text { experimental mice } \\
\text { (group A) }\end{array}$ & Types o treatment & Result \\
\hline First subgroup & $\begin{array}{c}\text { (Cefotaxime } \\
\text { sodium and } \\
\text { chamomile flower } \\
\text { ethanol extract) at } \\
50 \%\end{array}$ & $\begin{array}{c}\text { Complete cure } \\
\text { after 16 days }\end{array}$ \\
\hline Second subgroup & $\begin{array}{c}\text { Cefotaxime sodium } \\
\text { Third subgroup }\end{array}$ & $\begin{array}{c}\text { Complete cure } \\
\text { after 17 days }\end{array}$ \\
\hline Fourth subgroup & PBS & $\begin{array}{c}\text { Complete cure } \\
\text { after 22 days }\end{array}$ \\
\hline
\end{tabular}

Table 4: Effect of different treatments on curing of mice skin infected with $C$. albicans in four experimental mice subgroups

\begin{tabular}{|c|c|c|}
\hline $\begin{array}{c}\text { Sub grouping of } \\
\text { experimental mice } \\
\text { (group B) }\end{array}$ & Type of treatment & Result \\
\hline First subgroup & $\begin{array}{c}\text { (Clotrimazole and } \\
\text { chamomile flower } \\
\text { ethanol extract) at } 75 \%\end{array}$ & $\begin{array}{c}\text { Complete } \\
\text { cure after } \\
20 \text { days }\end{array}$ \\
\hline Second subgroup & Clotrimazole & $\begin{array}{c}\text { Complete } \\
\text { cure after } \\
25 \text { days }\end{array}$ \\
\hline Third subgroup & $\begin{array}{c}\text { Chamomile flower } \\
\text { ethanol extract }\end{array}$ & $\begin{array}{c}\text { Complete } \\
\text { cure after } \\
10 \text { days }\end{array}$ \\
\hline Fourth subgroup & PBS & $\begin{array}{c}\text { Died after } \\
8 \text { days }\end{array}$ \\
\hline
\end{tabular}




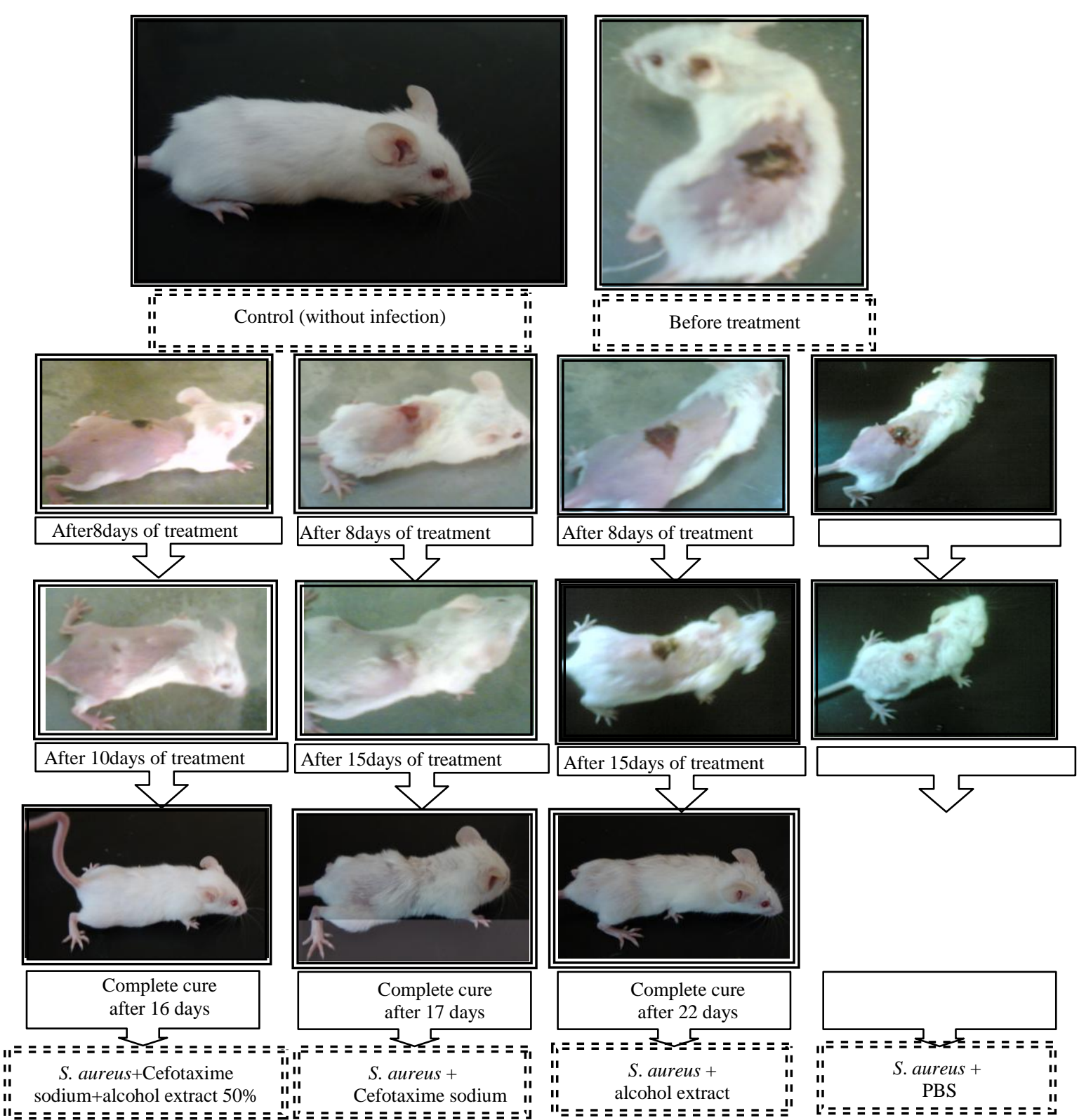

Fig. 2: Morphological repair of the skin infected by $S$. aureus and treated with a combination of Cefotaxime sodium + chamomile flower alcohol extract at 50\%, Cefotaxime sodium, chamomile flower alcohol extract and PBS.

HPLC chromatography of the used standards (apigenin and azulene) is shown in Fig. (3). Apigenin appeared at a retention time of 7.60 min. with a peak area of 1973157 mAU, while azulene appeared at a retention time of $20.72 \mathrm{~min}$. with a peak area of 778417 mAU.

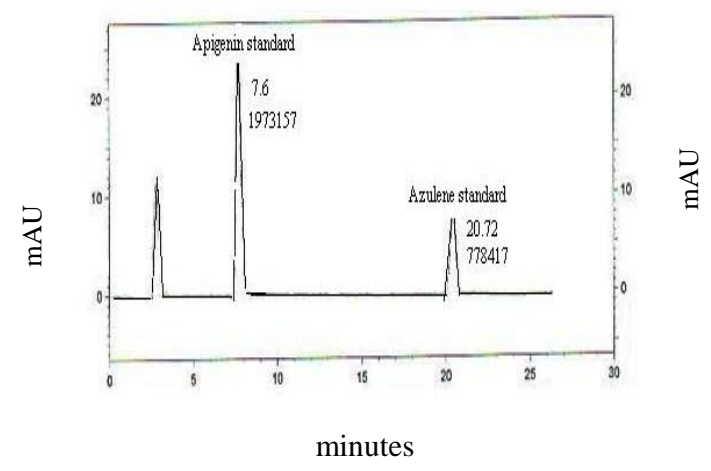

Fig. 3: HPLC analysis of apigenin and azulene standards 


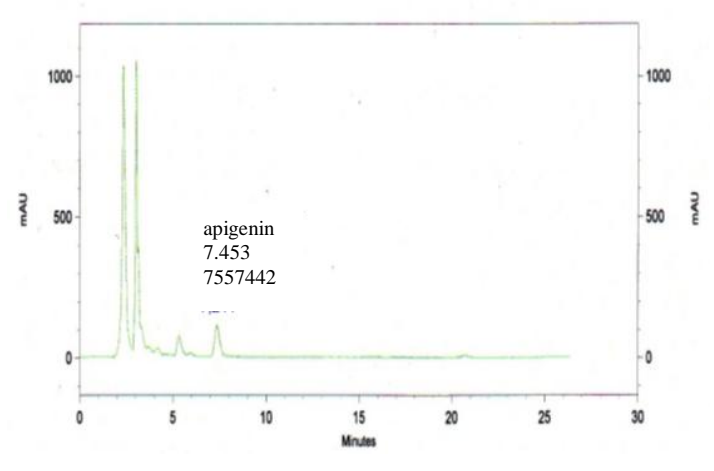

Fig. 4: HPLC of apigenin and azulene in chamomile flower ethanol extract showing appearance of the first compound and disappearance of the second.

Chamomile alcohol extract of apigenin and azulene is shown in Fig (4). Apigenin appeared at a retention time of 7.453 min. with a peak area $7557442 \mathrm{mAU}$ while azulene was not detected at a retention time of 7.453 min. The percentage of apigenin in alcohol extract represented $0.3064 \%$ of the crude extract.

\section{Discussion:}

Results displayed in table (1) were in agreement with AL-naymi [18] who reported that ethanol extracts of chamomile flowers have higher activity than water ones, suggesting that the activity of chamomile could be attributed to the existence of chamazulene, $\quad \alpha$ - bisabolol (sesquiterpenes) that showed high inhibition activity against $S$. aureus, Staphylococcus epidermidis, Streptococcus pyogenes, Streptococcus pneumoniae, Micrococcuse ssp. and $C$. albicans.

Results exhibited in table 2 indicated that Cefotaxime sodium has the highest inhibition on $S$. aureus and $P$. aeruginosa, but the most effective treatment against $C$. albicans was Clotrimazole solution, because the Cefotaxime sodium has high activity against microorganisms and the Clotrimazole solution has high activity against $C$. albicans. This may be due to the absorption of Cefotaxime sodium and Clotrimazole solution by skin (in vivo) during the treatment, and its activity had increased after addition of chamomile extract.

Results showed in table (3) and Fig. (2) exhibited that skin treated with Cefotaxime sodium used a complete cure after 16 days which was better than those treated with chamomile flower ethanol extracts.

Table (4) showed that mice skin treated with chamomile ethanol extracts was better since it rapidly recovered than those treated with the Clotrimazole. It appears that the presence of apigenin, the most active compound of chamomile, penetrates into deeper skin layers when applied topically which supports the use of chamomile as a topical antiinflammatory agent in treating inflammations in deep tissues $[19,20]$.

\section{References:}

1. Appelt, G. 1985. Pharmacological aspects of selected herbs employed in Hispanic folk medicine in San Luis Valley of Colorado, USA: Matricaria chamomilla. J. Ethnopharmacol., 13 (1): 51-55.

2. Chiej, R. 1984. Encyclopaedia of Medicinal Plants. MacDonald. Pp. 678-685.

3. Duke, J. A. and Ayensu, E. S. (1985). Medicinal Plants of China. Reference Publications, Inc., pp: 564-570.

4. Bown, D. 1995. Encyclopaedia of Herbs and their Uses. Dorling Kindersley, London., pp. 79-85.

5. Dagan, R. and Bar-David, Y. 1992. Double-blind study comparing erythromycin and mupirocin for treatment of impetigo in children: implications of a high prevalence of erythromycin-resistant 
Staphylococcus aureus strains. Antimicrob. Agents Chemother., 36: 287-290.

6. Kugelberg, E.; Norstrom, T.; Petersen, T. K.; Duvold, T.; Andersson, D. I. and Hughes, D. 2005. Establishment of a superficial skin infection model in mice by using Staphylococcus aureus and Streptococcus pyogenes. Antimicrob. Agents Chemother., 49 (8): 3435-3441.

7. Richmond, M. H. and Sykes, R. B. 1973. The ß-Lactamases of Gram-Negative Bacteria and their Possible Physiological Role, Advances in Microbial Physiol., 9: 31-88.

8. Togeas, and James, B. 2005. "Acetic Acid Vapor: 2. A Statistical Mechanical Critique of Vapor Density Experiments". J. Phys. Chem. A., 109: 5438-5440.

9. Howden, B. P. and Grayson, M. L. 2006. "Dumb and dumber - the potential waste of a useful antistaphylococcal agent: emerging fusidic acid resistance in Staphylococcus aureus". Clin. Infect. Dis., 42 (3): 394-400.

10. Duhm, B.; Medenwald, H. and Puetter, J. 1974. "The Pharmacokinetics of Clotrimazole 14C," Postgrad Med. J., 50 (1): 1316.

11. Santos-Buelga, C.; GarcíaViguera, C. and Tomás-Barberán, F. A. 2003. Online identification of flavonoids by HPLC coupled to diode array detection. In: Methods in Polyphenol Analysis (edited by C. Santos-Buelga and G. Williamson). Gateshead. UK: Athenaeum Press Ltd, pp. 92-127.

21. Nmecz, G. 2000. Herbal pharmacy: chamomile, this widely available herb has diverse therapeutic uses,
12. Liang, Y. Z.; Xie, P. and Chan, K. (2004). Quality control of herbal medicines. J. of Chromatography B., 812: 53-70.

13. Wills, R. B. H. and Stuart, D. L. 2004. Generation of high Quality Australian Skullcap Products. In: A report for the Rural Industries Research and Development Corporation. RIRDC Publication no 04/020.

14. Harborne, J. $\quad$ B. 1973. Phytochemical Methods. Science paper backs, Chapman Hall, London. pp. 49-88.

15. Nathan, C. 1978. In vitro activity of Sch 21420, derivative of gentamicin B compared to that of amikacin antimicrob. Agents Chemother., 14: 786- 787.

16. Adriana, E.; Andrea, P. and Miroslav R. K. 2004. Quantitative changes of secondary metabolites of Matricaria chamomilla by abiotic stress. Dept. of Botany, Institute of Biology and Ecology, Slovak Republic, pp. 543 - 548.

17. Benguo, L.; Zhengxiang, N.; Jianhua, G. and Keyong, X. 2008. Preparing apigenin from Adinandra nitida leaves. Food Technol. Biotechnol., 46 (1): 111115.

18. Al-naymi, H. A. 2005. Activity evaluation of some positive pathogenic bacteria isolated from pharyneitis and tonsillitis cases. MSc. Thesis, College of medicine, University of Baghdad, Iraq.

19. Merfort, I. and Heilman, J. 1994. In vivo skin penetration studies of chamomile flavones. Pharmazie., 49 (7): 509-511.

20.

including anti phlogistic, sedative and antimicrobial effects, U. S. Pharmacist, 23: 115-123 


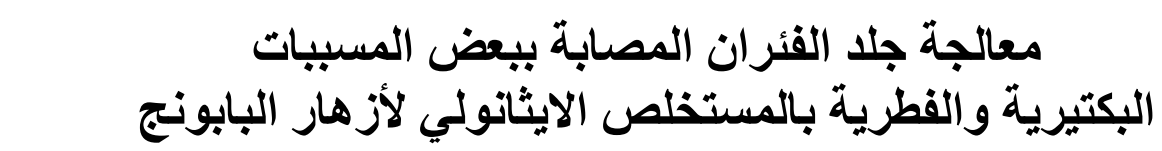

منبرة جلوب اسعاعيل م**

كاطم محمد إبرا هيمث*

إبناس حسبن عليثيث

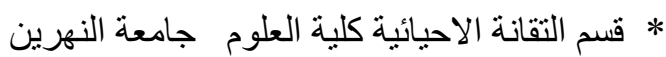
2** مركز البحوث البايولوجية للمناطق الحارة - جامعة بغداد النين

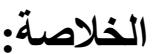

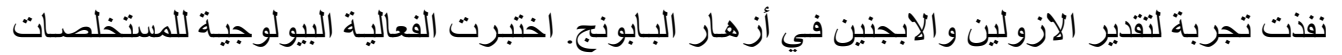

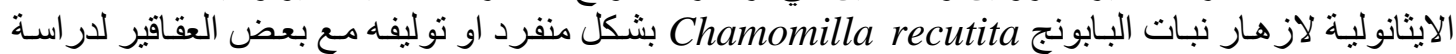

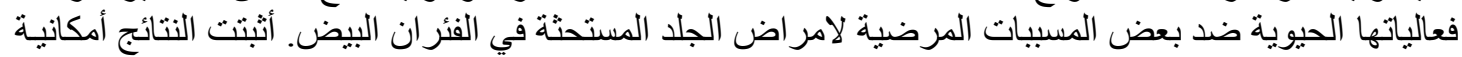

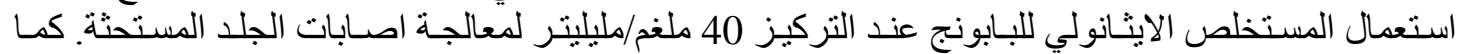

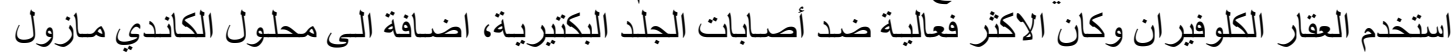

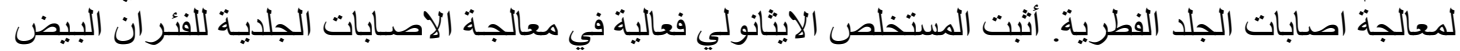

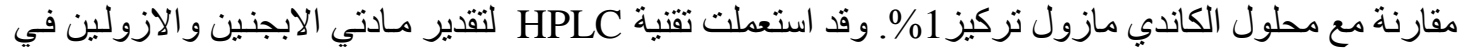

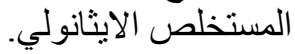

